\title{
BABALLARET E KOMBIT - CHARAKTERYSTYKA I AKTYWNOŚĆ ALBAŃSKICH ELIT POLITYCZNYCH W TOKU I WOJNY BAŁKAŃSKIEJ
}

\author{
TADEUSZ CZEKALSKI
}

\begin{abstract}
Tadeusz Czekalski, Baballaret e Kombit - charakterystyka i aktywność albańskich elit politycznych $w$ toku I wojny batkańskiej (The Nation Fathers (Baballaret e kombit). Description and form of activities of Albanian political elites during First Balkan War).
\end{abstract}

Balcanica Posnaniensia. Acta et studia, XIX, Poznań 2012, Wydawnictwo Instytutu Historii UAM, pp. 197-206, ISBN 978-83-63-047-17-7, ISSN 0239-4278. Polish text with a summary in English.

Tadeusz Czekalski, Uniwersytet Jagielloński, Instytut Historii, ul. Gołębia 13, Kraków.

Trudno przecenić w historiografii albańskiej rolę, jaką odgrywa data 28 listopada 1912 r. - dzień proklamowania we Vlorze Deklaracji Niepodległości. Niezależnie od opcji politycznej Albańczycy zdają się być konsekwentni w łączeniu tej daty z początkiem istnienia niepodległego państwa po ponad 400-letniej niewoli osmańskiej. Rozgrywające się w tle wydarzeń I wojny bałkańskiej działania albańskich działaczy narodowych stanowią do dzisiaj kanoniczny element albańskiej historiografii, który w niewielkim stopniu jest przedmiotem dyskusji historyków, a zarazem poddawany naukowej weryfikacji.

Teza o konsekwentnie wrogiej wobec Imperium Osmańskiego postawie ludności albańskiej na przestrzeni dziejów zdaje się potwierdzać aktualne oczekiwania polityczne w Tiranie, ale zarazem ignoruje znaczący udział osób pochodzenia albańskiego w rozwoju administracji osmańskiej i sił zbrojnych Imperium. Znany albański działacz narodowy Sami Frasheri w 1878 r. pisał o fenomenie „podwójnej lojalności” - zarówno wobec Imperium Osmańskiego, jako „podstawowej ojczyzny” (vatan -i umumi) oraz wobec Albanii, jako „specjalnej ojczyzny” (vatan-i hususi)'. William Sloane określał ziemie albańskie w Imperium Osmańskim jako naturalną barierę

${ }^{1}$ G. Gawrych, Tolerant Dimensions of Cultural Pluralism in the Ottoman Empire: The Albanian Community 1800-1912, „International Journal of Middle East Studies”, vol. 15, No. 4, (Nov. 1983), s.524. 
przeciwko ekspansji serbskiej w kierunku Morza Adriatyckiego ${ }^{2}$. Nie zmieniło tej opinii w sposób znaczący powołanie w 1878 r. tzw. Ligi Prizreńskiej, której działacze kontestowali nie tyle władzę Porty Osmańskiej co raczej możliwość podziału ziem albańskich, stanowiących dotąd integralną część państwa osmańskiego ${ }^{3}$. Po upadku Ligi Prizreńskiej kolejne pokolenie albańskich działaczy narodowych skoncentrowało swoją uwagę na działalności edukacyjnej i oświatowej. Ich dziełem były pierwsze szkoły z językiem albańskim, a także standaryzacja języka albańskiego, od 1908 r. zapisywanego już konsekwentnie w alfabecie łacińskim. Przełomem w historii albańskiego ruchu narodowego był rok 1908 i kongres monastyrski, który był jednym z finalnych akcentów w ,pozytywistycznej” fazie albańskiego Odrodzenia Narodowego. Uczestnicy kongresu oprócz ustaleń dotyczących alfabetu przyjęli także postulat rozwoju szkolnictwa albańskiego w Imperium Osmańskim, powtarzając zarazem postulat o autonomii ziem zamieszkanych przez Albańczyków.

Okres poprzedzający rewolucję młodoosmańską 1908 r. przyniósł konsolidację albańskiego ruchu narodowego wokół kwestii edukacyjno-kulturalnych, ale także coraz wyraźniejszych i sprecyzowanych programów politycznych, stawiających pytania o przyszłość Albańczyków w Imperium Osmańskim. Wśród nich szczególne znaczenie można przypisać dziełu Samiego Frasheriego (Albania - czym była, czym jest i czym będzie) z 1899 r., ale także wypowiedziom Ismaila Qemala, który w w wywiadzie dla włoskiej „Tribuny” w 1900 przedstawiał projekt albańskiej autonomii. O jedność wszystkich Albańczyków apelował w styczniu 1902 r. Giovanni de Aladro Castriota, hiszpański dyplomata, uważający się za potomka Skanderbega, deklarując, że jest gotów walczyć o odrodzenie Albanii ${ }^{4}$. Albański ruch narodowy w początkach XX w. nie był już, jak trzydzieści lat wcześniej lokalnym i marginalnym zjawiskiem w życiu politycznym Imperium Osmańskiego. Współpraca albańskiej diaspory w Rumunii, Bułgarii, Egipcie, we Włoszech i w Stanach Zjednoczonych prowadziło do widocznego rozwoju albańskiego rynku wydawniczego, ale także do umiędzynarodowienia sprawy albańskiej i poszukiwania kontaktów w środowiskach politycznych Włoch czy Rumunii. Przykładem rosnących wpływów politycznych diaspory był Albański Kongres Narodowy, zorganizowany w kwietniu 1904 r. w Bukareszcie, pod patronatem ks. Alberta Ghica ${ }^{5}$. Wzrost wpływów Albańczyków we Włoszech Stavro Skendi kojarzy z rolą, jaką odegrał premier Włoch Francesco Crispi (,Albańczyk z krwi i z serca") ${ }^{6}$.

Doświadczeniem istotnym, choć krótkotrwałym dla polityków albańskich stał się epizod parlamentarny z 1908 r. W gronie 288 deputowanych zasiadających w parlamencie osmańskim znalazło się dwudziestu sześciu Albańczyków. Nie stanowili śro-

2 W. Sloane, Turkey in Europe, „Political Science Quarterly” vol. 26, No. 4 (Dec. 1911), s.682

3 S. Skendi, Beginnings of Albanian Nationalist and Autonomous Trends: The Albanian League 1878-1881, „American Slavic and East European Review”, vol. 12 , No. 2, (Apr. 1953), s.225-226.

${ }^{4}$ S. Skendi, Albanian Political Thought and Revolutionary Activity, 1881-1912, „Sudost Forschungen" 13 (1954), s.169.

${ }^{5}$ E. Stickney, Southern Albania 1912-1923, New York 1926, s.14.

${ }^{6}$ S. Skendi, op.cit., s. 170. 
dowiska jednolitego politycznie, ale reprezentowali coraz bardziej aktywne albańskie kluby polityczne, które w 1908 r. powstawały w Stambule, Salonikach, Skopju, a także na ziemiach dzisiejszej Albanii.

Nadzieje na ograniczoną modernizację Imperium przy zachowaniu jego wieloetnicznego charakteru już w 1909 r. okazały się nierealne. Przewrót kwietniowy w Stambule i przejęcie władzy przez młodoosmański komitet „Jedność i postęp” przyniósł realne zagrożenie przekształcenia wieloetnicznego Imperium, w jednolite, scentralizowane państwo. Dla większości Albańczyków scenariusz centralizacji kłócił się z tradycyjną autonomią, którą cieszyli się przez pokolenia, ale także ograniczał prawa języka albańskiego. Po 1908 r. nawet na poziomie administracji lokalnej na terenach zdominowanych przez ludność nie-turecką, od urzędników oczekiwano, aby w swojej pracy posługiwali się językiem tureckim ${ }^{7}$. Dla wielowyznaniowej ludności albańskiej tradycyjna autonomia ściśle skorelowana z zasadami prawa zwyczajowego oraz swoboda posługiwania się językiem ojczystym stanowiły fundament swoistego „paktu o nieagresji”. Większość wystapień i buntów antyosmańskich, które w XIX w. regularnie wstrząsały ziemiami albańskimi miało wyraźny charakter buntów antypodatkowych ${ }^{8}$.

Albańczycy z niepokojem reagowali na kolejne przejawy polityki centralizacyjnej władz osmańskich. Drogą do likwidacji albańskiej autonomii miało być przeprowadzenie spisu powszechnego, a także „ustawa o bandach", sankcjonująca możliwość stosowania zasady odpowiedzialności zbiorowej w przypadku jakichkolwiek działań antypaństwowych. Przywiązani do przywilejów i luźnego związku z państwem osmańskim przywódcy północnej Albanii byli zdecydowani przeciwstawić się wszystkimi dostępnymi środkami polityce „turkifikacji”"

Latem 1909 r. konfrontacja wydawała się nieunikniona. Rolę inicjującą odegrały muzułmańskie klany z Kosowa, które zjednoczyły się pod wodzą Isy Boletiniego i opanowały okolice Mitrovicy. Wiosną 1910 r. powstanie rozszerzyło się na cały obszar Kosowa, a kolejne próby jego pacyfikacji przez oddziały tureckie przynosiły efekty ograniczone i krótkotrwałe. Rok później powstały na wyspie Korfu Albański Komitet Centralny koordynował przygotowania do powstania ogólnonarodowego. Kolejne oddziały powstawały nie tylko w Kosowie i w okolicach Szkodry, ale także w rejonie Elbasanu i Korczy.

Stephen Duggan pisząc o bałkańskich problemach Turcji, nazwał Albanię „tureckim Ulsterem", podkreślając zarazem, że idea walki przeciwko turkifikacyjnym działaniom młodoosmanów zjednoczyła ze sobą muzułmańskie klany z Kosowa i katolic-

${ }^{7}$ H. Millas, Non-Muslim Minorities in the Historiography of Republican Turkey: the Greek Case, [w:] The Ottomans and the Balkans. a Discussion of Historiography, ed. F. Adanir, S. Faroqhi, Leiden \& Boston 2002, s.163. Wg George'a Gawrycha aż 66 \% urzędników osmańskich na Bałkanach znało język albański, a 1.8 \% kadry urzędniczej znało tylko język albański - G. Gawrych, op.cit., s.522.

${ }^{8}$ I. Sienkiewicz, Albania w period wostocznowo krizisa 1875-1881 g., Moskwa 1965, s.66-77; I. Smirnowa, Oswoboditielnoje dwiżenije albanskowo naroda w 1905-1912 g., Moskwa 1959, s.61;

${ }^{9}$ S. Skendi, op.cit., s.197. 
kie plemię Mirdytów ${ }^{10}$. Powstanie albańskie, które z przerwami toczyło się w latach 1910-1911 w kolejnych dokumentach programowych przedstawiało dwa zasadnicze cele: zachowanie autonomii ziem albańskich i gwarancję niepodzielności terytoriów zamieszkanych przez ludność albańskojęzyczną. Wystąpienia parlamentarne Hasana Prishtiny, który w styczniu 1912 r., w imieniu albańskich deputowanych przestrzegał przed lekceważeniem problemu albańskiego przyspieszyły eliminację z parlamentu deputowanych albańskich, którym zablokowano możliwość ubiegania się o mandat w nowych wyborach. Albańscy politycy przyłączyli się do powstania, które latem 1912 r. doprowadziło do paraliżu administracji osmańskiej na ziemiach dzisiejszej Albanii, Kosowa i Macedonii. 13 sierpnia 1912 r. pierwsze oddziały powstańcze wkroczyły do Skopja, a kolejne przekroczyły rzekę Shkumbini, kierując się w stronę Salonik ${ }^{11}$.

Wśród przywódców powstania nie było jedności, co do przyszłości ziem albańskich. Bardziej radykalni w swoich poglądach przywódcy z Kosowa (Hasan Prishtina, Bajram Curri), dążyli do administracyjnego wyodrębnienia ziem albańskich w ramach państwa osmańskiego. Bardziej konserwatywni właściciele ziemscy z południowej Albanii domagali się jedynie zwiększenia politycznej reprezentacji Albanii w parlamencie osmańskim. Oba te środowiska jednoczyły obawy o to, że w obliczu kryzysu państwo osmańskie zrezygnuje z części swojego terytorium na rzecz państw bałkańskich. Obawy te nasiliły się w sposób szczególny po wybuchu I wojny bałkańskiej w październiku 1912.

Armie państw bałkańskich, operujące na terytoriach zamieszkanych przez Albańczyków zachowywały się jak siły okupacyjne. Pisząc o I wojnie bałkańskiej, Constantine Chekrezi używa określenia ,inwazja Albanii”, uznając za symptomatyczny fakt, że serbscy kawalerzyści, którzy w Durres dotarli do wybrzeża, krzyczeli „Niech żyje serbskie morze"12. W obliczu inwazji, w środowisku albańskich działaczy narodowych miejsce programu autonomicznego zajmowało coraz wyraźniej akcentowane słowo pamvaresia (niezależność), co oznaczało konieczność poszukiwania dla sprawy albańskiej sojuszników spoza Bałkanów. Rolę wiodącą przyjął na siebie jeden z b. deputowanych do parlamentu osmańskiego Ismail Qemal, który od lat był cenionym w Rzymie i w Wiedniu rzecznikiem sprawy albańskiej ${ }^{13}$. W przekonaniu Qemala, istniejący układ sił w Europie powodował, że jedyną szansą na obronę jedności ziem albańskich było porozumienie z przeciwnikami Serbii - Austro-Węgrami

10 S. Duggan, European Diplomacy and the Balkan Problem, „Political Science Quarterly” vol.28, No. 1 (Mar. 1913), s.110.

11 Sh. Braha, Idriz Seferi në Lëvizjet Kombëtare Shqiptare, Tiranë 1981, s. 179.

12 C. Chekrezi, Albania - Past and Present, New York 1919, s. 77.

${ }^{13} \mathrm{~W}$ gronie albańskich działaczy niepodległościowych, Ismal Qemal Vlora (1844-1919) był jedynym przykładem szybkiej i efektownej kariery politycznej w strukturach państwa osmańskiego. W $1860 \mathrm{r}$. rozpoczął pracę jako tłumacz w ministerstwie spraw zagranicznych, osiem lat później awansował na stanowisko sekretarza generalnego MSZ, a w 1870 r. (mając zaledwie 26 lat) obją prestiżowe stanowisko gubernatora w Warnie. Ze służby w administracji osmańskiej odszedł w 1900 r. - B. Gaçe, Ata, që shpallen Pavarësinë Kombëtare, Tirane 2002, s.11-16. 
i Włochami. Równolegle z działalnością dyplomatyczną, na ziemiach albańskich podjęto przygotowania do zwołania zgromadzenia przedstawicielskiego (kuvendi perfaqesues), które miało odbyć się w Durres albo we Vlorze. Zajmowała się tym specjalna komisja, powołana we Vlorze. Idea tego typu zgromadzenia (kuvendi) nawiązywała do podobnych, działających w latach 1910-1912, które miały na celu koordynację działań powstańczych i wypracowanie wspólnego stanowiska, co do przyszłości ziem albańskich. Tym razem jednak najważniejsze decyzje, nad którymi mieli obradować delegaci przyszłego zgromadzenia, zapadały poza Albanią. Po wybuchu I wojny bałkańskiej, od października 1912 r. centrum decyzyjne przeniosło się do Bukaresztu. Swoboda działania w Rumunii, silne i wpływowe kluby patriotyczne, a także zamożna diaspora tworzyły doskonałe warunki do działań, które zaplanowane w Bukareszcie, miały być zrealizowane na ziemiach albańskich. W środowisku tym powstały też pierwsze struktury władzy, które można określić zalążkiem przyszłego rządu $^{14}$. Po zakończeniu obrad w Bukareszcie, Qemal mógł już z pełnym przekonaniem pisać do swojego syna we Vlorze - ,nadejście Albanii jest przesądzone”15.

Istotną przeszkodą na drodze do realizacji planów Qemala mógł być szybko postępujący rozkład armii osmańskiej i postępy wojsk serbskich. Serbska III armia (dow. gen. Božidar Janković), po zajęciu Kosowa, skierowała się w stronę albańskiego wybrzeża Adriatyku. Dnia 17 listopada 1912 r. pierwsze oddziały serbskie przekroczyły Biały Drin i zajęły Lezhë (Alessio), a 26 listopada - Tiranę. Przeciwnikiem Serbów w tej fazie działań były resztki 6 Korpusu Dżawida Paszy (rozbitego 1617 listopada w bitwie pod Bitolą), coraz częściej wspierane przez oddziały powstańców albańskich ${ }^{16}$. Podążające od południa jednostki armii greckiej 4 listopada zajęły Prevezę. Zmodernizowane z pomocą niemiecką fortyfikacje Janiny, wzmocnione przez żołnierzy z jednostek rozbitych pod Bitolą zablokowały dalsze postępy Greków w Epirze ${ }^{17}$.

Mimo trwających działań wojennych, Qemal zdecydował się na powrót do Albanii wraz z grupą współtowarzyszy, korzystając z pomocy Wiednia. Austriacki parowiec Bruenn, na pokładzie którego znalazło się czternastu Albańczyków wypłynął 20 listopada z Triestu i dzień później dotarł do portu w Durres, zanim pojawiły się tam pierwsze jednostki armii serbskiej ${ }^{18}$. z Durres Qemal wraz z towarzyszami wyruszył w dalszą drogę konno, (dłuższą ale bezpieczniejszą drogą przez równinę Myzeqe), by 25 listopada dotrzeć do Vlory. Opis trudności, które miały stwarzać Qemalowi w jego misji władze osmańskie, tak chętnie podnoszony niegdyś w historiografii albańskiej

14 W raporcie z obrad, toczących się w Bukareszcie w dniach 4-5 listopada znalazła się informacja o powołaniu ,komisji, złożonej z Albańczyków znanych w Europie, którzy mają w przyszłości bronić praw narodowych ludu albańskiego" - Ismail Qemali. Permbledhje dokumentesh (1888-1919), opr. T. Hoxha, Tirana 2002, s.245-246.

15 w oryg. alb.: E ardhmja e Shqipërise është e siguruar - Ismail Qemali, op. cit, s.246.

16 R. C. Hall, The Balkan Wars 1912-1913. Prelude to the First World War, London \& New York 2005, s.54.

17 Ibidem, s.63.

18 C. Chekrezi, op.cit, s.79. 
wydaje się raczej nieporozumieniem. Niewątpliwie można mówić o niechęci władz osmańskich wobec Qemala w początkach 1912 r., kiedy uniemożliwiono prowadzenie mu otwartej działalności politycznej przed zbliżającymi się wyborami parlamentarnymi. W listopadzie 1912 r. sytuacja polityczna zmieniła się radykalnie, a cena Qemala dla Stambułu wyraźnie wzrosła. Dokumenty dotyczące misji Ismaila Qemala, wydane przez Teutę Hoxhę, zebrane w trakcie kwerendy w archiwach Stambułu i Wiednia zdają się wskazywać na to, że o misji Qemala i prawdziwych jego zamiarach wiedziano nie tylko w Wiedniu i Rzymie, ale też w Stambule. Rozkaz aresztowania Qemala, wydany 19 listopada 1912 r. przez dowódcę żandarmerii w Janinie, jeszcze w tym samym dniu został anulowany ${ }^{19}$. Co więcej, $w$ jednym $z$ dokumentów odnajdujemy sugestię, skierowaną do urzędnika osmańskiego w Stambule, aby ten godnie i z honorami przywitał Qemala i jego otoczenie ${ }^{20}$. Trudno też znaleźć informacje o tym, aby Turcy utrudniali czy uniemożliwiali dotarcie do Vlory delegatów albańskich z ziem, które jeszcze pozostawały pod ich kontrolą. Działo się tak, mimo toczących się nadal działań wojennych i trudności komunikacyjnych.

Kiedy w listopadzie 1912 r. rozpoczynały się obrady Zgromadzenia we Vlorze, nie żyła już większość działaczy narodowych z tzw. pierwszego pokolenia, kojarzonych z działalnością w ramach Ligi Prizreńskiej. W gronie żywych nie było też braci Frashëri (Abdyl, Naim, Sami), wyjątkowo aktywnych w środowisku stambulskim, a uważanych za głównych ideologów albańskiego Odrodzenia Narodowego ${ }^{21}$. W czasie obrad Zgromadzenia w listopadzie 1912 r., „sułtan Vlory” jak określano Qemala w jego rodzinnym mieście nie miał poważniejszych konkurentów do władzy, ani też osób cieszących się porównywalnymi wpływami i prestiżem. W gronie albańskich działaczy narodowych stanowił wyjątek - od lat był znany włoskiej i francuskiej opinii publicznej, a jako były deputowany i przywódca partii Ahrar posiadał także doświadczenie polityczne. Uchodził też za polityka ostrożnego i umiarkowanego. z grona byłych deputowanych albańskich wywodził się też reprezentant Kosowa - Hasan Prishtina, ale sądząc po jego późniejszych dokonaniach, jeśli nawet dorównywał ambicjami Qemalowi, był przede wszystkim powstańcem, bez doświadczenia i talentu politycznego cechujących ,sułtana Vlory”.

Po trzydniowych przygotowaniach, obrady Zgromadzenia Narodowego (Kuvendi Kombëtar) rozpoczęły się we Vlorze 28 listopada 1912 r. Przewodniczył im muzułmański duchowny Vehbi Dibra (Agolli), ale sprawy organizacyjne nadzorował osobiście Qemal22. Już w pierwszym dniu obrad Zgromadzenie proklamowało Deklarację

${ }^{19}$ N. Nika, Përmbledhje dokumentesh mbi kryengritjet shqiptare (1910-1912), Prishtinë 2003, s.358-359 .

${ }^{20}$ Ismail Qemali, op. cit, s.248-249.

${ }^{21}$ K. Frashëri, Tre Vellezer Pishtare: Abdyl Frashëri, Naim Frashëri, Sami Frashëri, Tiranë 1978. Prestiż, którym cieszyła się w Albanii rodzina Frashëri miał w Albanii ogromne znaczenie, czego dowodem była kariera, która w latach 1912-1914 stała się udziałem nieznanego wcześniej w albańskim środowisku niepodległościowym - Mithata Frashëriego.

$22 \mathrm{~W}$ dniu ogłoszenia niepodległości Vehbi Dibra w imieniu duchowieństwa muzułmańskiego wydał fetwę, w której uznawał Deklarację Niepodległości jako „dar od Boga” - E. Gjinishi, The Historical 
Niepodległości. Dokument, który przyjęto praktycznie bez dyskusji jest dwujęzyczny (po albańsku i turecku) i wyjątkowo lakoniczny. Jego albańska część zawiera zaledwie kilka zdań:

We Vlorze, dnia 15/28 listopada 1328/1912.

Po wygłoszeniu przemówienia przez przewodniczącego, Ismaila Kemala Beja, w którym mówił o wielkich nieszczęściach, których doświadcza dzisiaj Albania, wszyscy delegaci zdecydowali jednomyślnie, że Albania, tak jak dzisiaj powinna być samodzielna, wolna i niezależna ${ }^{23}$.

Oryginalny tekst Deklaracji Niepodległości (http://fjalaelire.co.uk, data dostępu 23 X 2012)

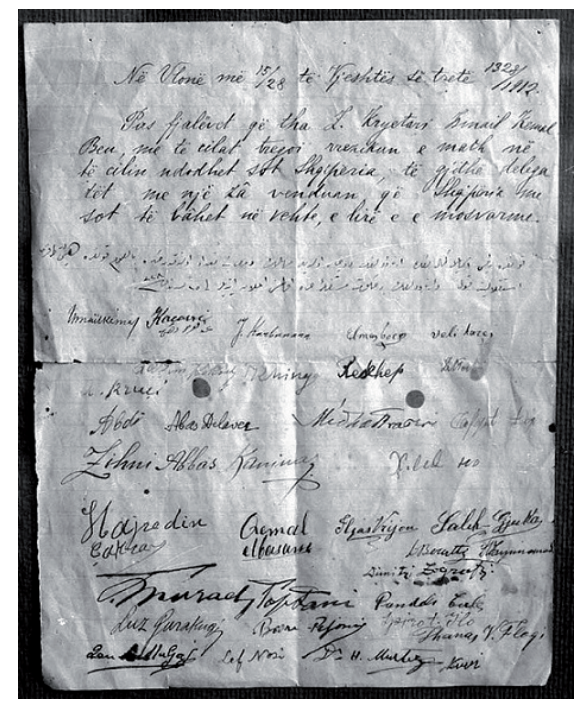

Drugą decyzja, podjętą w pierwszym dniu obrad Zgromadzenia było powołanie rządu (qeveria), na czele którego miał stanąć Qemal, a jego zastępcą wybrano księdza katolickiego Nikollę Kaçorriego. Drugim organem władzy, który powołano do życia na drugim posiedzeniu Zgromadzenia był Senat (pleqsia), który miał składać się z osiemnastu osób.

Korespondencja sygnowana przez Qemala z listopada 1912 r. sugeruje, że tak naprawdę o tym, co się stanie we Vlorze przesądzono już w październiku na posiedzeniu niewielkiego grona współpracowników Qemala w Bukareszcie ${ }^{24}$. Opublikowany

Background to the Muslim Community in Albania During the Period 1912-1920, [w:] Strengthening Religious Tolerance fo a Secure Civil Society in Albania and the Southern Balkans, ed. J. Pettifer, M. Nazarko, Amsterdam 2007, s 57.

${ }^{23}$ W języku oryginału: Ne Vlorë më $15 / 28$ te vjeshtës së tretë 1328/1912. Pas fjalëvet që tha z. kryetari, Ismail Kemal beu, me të cilat tregoi rrezikun e madh në të cilin ndodhet sot Shqipëria, të gjithë delegatët me një za venduan që Shqipëria me sot të bahet në vehte, e lirë e e mosvarme - Akte të Rilindjes Kombëtare Shqiptare 1878-1912, opr. S. Pollo, S. Pulaha, Tiranë 1978, s.261.

${ }^{24}$ Shqipenija me 1937. Veprimi Shtetnor gjat njëzet e pesë vjeteve të pare të vetqeverimit, tom. 1, Tiranë 1937, s.35. 
w 1937 r. stenogram pierwszego posiedzenia Zgromadzenia wskazuje, że głosowanie nad projektem Deklaracji odbyło się zaraz po przemówieniu Qemala i bez przeprowadzenia dyskusji. Deklaracja vlorska, bardzo ascetyczna w treści była z czasem mylona z innymi przekazami, powstałymi później i niejako nawiązującymi do tekstu Deklaracji. Dotyczy to zwłaszcza rzekomego orędzia Qemala, które wygłosił z balkonu we Vlorze, a także telegramów, które z Vlory wysłano do mocarstw europejskich, informując o powstaniu państwa albańskiego.

Do kogo należy odnieść zakorzenione od lat 30. w albańskiej tradycji pojęcie „ojcowie narodu" (baballaret e kombit)? Historiografia albańska pojęcie to odnosi zazwyczaj do 77 przedstawicieli lokalnych społeczności albańskich, którzy zostali wydelegowani na obrady, a ich pełną listę zamieściło pismo „Perlindja e Shqipnies”, oficjalny organ rządu, utworzonego we Vlorze ${ }^{25}$. Faktycznie pod Deklaracją Niepodległości podpisało się zaledwie 40 osób, czyli ci, którym udało się na czas dotrzeć na miejsce obrad. W następnych dniach liczba delegatów we Vlorze przekroczyła 50 osób, ale ich podpisów nie odnajdziemy na oryginalnym dokumencie ${ }^{26}$. Wyliczenia realnej liczby sygnatariuszy wydają się uzasadnione, kiedy rozpatrujemy kwestię reprezentatywności Zgromadzenia. Czy istotnie we Vlorze spotkali się przedstawiciele większości ziem albańskich? Większość delegatów z północnej części kraju nie dotarła na obrady z powodu trudności komunikacyjnych, pogłębionych przez działania wojenne. Niektórzy z delegatów Kosowa zostali zatrzymani i znaleźli się w więzieniach serbskich za prowadzenie działalności wywrotowej. We Vlorze nie pojawili się przywódcy powstańczy z lat 1910-1912, ale także przedstawiciele aktywnego środowiska szkoderskiego. Co prawda Szkodrę reprezentował Luigji Gurakuqi, jeden z najbliższych współpracowników Qemala, ale w praktyce od kilku lat działał poza krajem i był bardziej znany w Bukareszcie niż w swoim rodzinnym mieście.

Brak przedstawicieli północnej części Albanii we Vlorze stawiał pod znakiem zapytania możliwość zastosowania w praktyce zasady konsensusu wyznaniowego. W gronie delegatów znalazło się zaledwie dwóch przedstawicieli społeczności katolickiej, skupiającej ok. $10 \%$ ludności kraju ${ }^{27}$. Wyjątkowo licznie pojawiła się we Vlorze reprezentacja Ochrydu i Strugi, a także okolic Peje-Gjakove (Peć-Djakovica). Wraz z Qemalem przybyła do Vlory także liczna reprezentacja albańskiej diaspory, złożona prawie wyłącznie z przedstawicieli pochodzących z Rumunii (jeśli nie liczyć Spiridona Ilo, który większość swojego życia spędził w USA, ale do Vlory przyjechał jako przedstawiciel Korczy).

W gronie delegatów dominowali ludzie stosunkowo młodzi, jak na warunki albańskie ${ }^{28}$. Ośmiu delegatów, zebranych we Vlorze liczyło niespełna 30 lat życia, i to właśnie oni, jak można przypuszczać odegrali istotną rolę w organizacji zaplecza ob-

\footnotetext{
25 B. Gaçe, op.cit., s. 5.

${ }^{26}$ Shqipenija me 1937, op.cit., s.37.

${ }^{27}$ Wśród sygnatariuszy Deklaracji Niepodległości poza Gurakuqim znalazł się proboszcz katolickiej parafii w Durrës - Nikolle Kaçorri, poźniejszy wicepremier w rządzie Ismaila Qemala.

${ }^{28}$ Informacje biograficzne na podst. B. Gaçe, op.cit., s.11-199.
} 
rad, a następnie w tworzeniu administracji lokalnej. Byli wśród nich młodzi prawnicy, którzy zdobywali wykształcenie w Stambule i Atenach - Thanas Floqi, Dhimiter Berati i Mustafa Kruja. We Vlorze, pod kierunkiem Qemala zaczynali swoje długie i efektowne kariery polityczne. Średnią wieku delegatów (39.7 lat) zawyżało kilka osób, które przekroczyły sześćdziesiąty rok życia. Wśród tych ostatnich był sam Qemal, ale także cieszący się powszechnym szacunkiem w południowej Albanii Baba (Jorgji) Dud Karbunara ${ }^{29}$. Włączenie Karbunary do składu Zgromadzenia, podobnie jak wiekowego nauczyciela Elmaza Boçe (ur. 1850), miało wymiar symboliczny. Obaj działali w strukturach Ligi Prizreńskiej i współpracowali z pierwszym pokoleniem tzw. Rilindaset (odrodzeniowców). Historia życia urodzonego w $1842 \mathrm{r}$. Karbunary stanowiła właściwie zapis ewolucji albańskiego ruchu narodowego - od działalności zbrojnej w ramach Ligi Prizreńskiej poprzez tworzenie szkół albańskojęzycznych aż do opracowywania memorandów politycznych. Doświadczenia sięgające Ligi Prizreńskiej były jednak obce większości delegatów, którzy z reguły działalność w ruchu narodowym rozpoczynali w latach 1906-1908 (najczęściej jako nauczyciele), a tylko nieliczni działali już w latach 1898-1900.

Zastanawiające mogą wydawać się dane o poziomie wykształcenia delegatów, zebranych we Vlorze. Aż 60 \% spośród nich deklarowało w 1912 r. posiadanie wykształcenia wyższego lub półwyższego, a blisko $25 \%$ wykształcenia średniego (wśród tych ostatnich był także Qemal). Informacje te należałoby zweryfikować, sięgając do danych bardziej szczegółowych. Aż połowa osób, deklarujących wykształcenie wyższe lub półwyższe kształciła się w Stambule, zwykle w szkołach przeznaczonych dla administracji publicznej lub w szkołach wojskowych. Co czwarty spośród tej grupy legitymował się dyplomem uniwersytetu ateńskiego. Pojedyncze osoby ukończyły studia wyższe w Europie Zachodniej ${ }^{30}$. Nieliczne osoby mogły się pochwalić jakimkolwiek doświadczeniem z pracy w administracji osmańskiej. Oprócz omawianego wcześniej Qemala, jeden z delegatów miał za sobą pracę na stanowisku prefekta Skraparu (Shefqet Daiu), zaś Xhelal Koprencka w przeszłości był dowódcą żandarmerii w Janinie. Doświadczeniem pracy na niższych stanowiskach w administracji osmańskiej mogli się poszczycić Hajredin Cakani, Abaz Celkupa i Nuri Solliu. Wśród delegatów najliczniejszą grupę stanowili nauczyciele - dla $32 \%$ delegatów praca w szkole była podstawowym źródłem utrzymania. Dla części delegatów, zwłaszcza ze środkowej i południowej Albanii podstawowym źródłem utrzymania były majątki ziemskie, ale doraźnie zajmowali się działalnością handlową. Wśród delegatów, którzy przyjechali z Bukaresztu podstawowe źródło utrzymania stanowił handel, choć równie chętnie deklarowali wykonywanie zawodu dziennikarza.

Stworzony we Vlorze rząd Ismaila Qemala formalnie rozpoczął działalność 4 grudnia 1912 r. i sprawował władzę przez kolejne sześć miesięcy. Nie miał on jed-

29 J. Faensen, Die albanische Nationalbewegung, Wiesbaden 1980, s.115.

${ }^{30}$ Studia prawnicze w Paryżu miał ukończyć Salih Gjuka, zaś Luigji Gurakuqi studia medyczne w Neapolu. Ukończenie studiów prawniczych na niesprecyzowanej bliżej uczelni niemieckiej deklarował Bedri Pejani. (zob. B. Gaçe, op.cit., s. 89, 154) 
nak większego wpływu na decyzje dotyczące przyszłości Albanii. Konferencja ambasadorów sześciu mocarstw europejskich, która zebrała się w Londynie w grudniu 1912 r. uznała niezależność Księstwa Albanii, które znalazło się pod protektoratem mocarstw. Po dymisji rządu Ismaila Qemala, większość sygnatariuszy Deklaracji Niepodległości znalazła się poza obszarem aktywności politycznej, a wybuch I wojny światowej zdawał się przekreślać ich plany i unicestwiać ideę albańskiej niepodległości. Grupa najstarszych wiekiem „ojców narodu” (w tym sam Qemal) nie doczekała odbudowy państwa albańskiego w 1920 r. Część najmłodszych baballaret, a zwłaszcza grupa właścicieli ziemskich z południowej Albanii podjęła aktywną działalność polityczną w okresie międzywojennym, a nieliczni spośród nich także w czasie II wojny światowej. Działaczy znanych z działalności antykomunistycznej (Qazim Kokoshi, Mustafa Kruja, Bedri Pejani), którzy zostali zgładzeni lub skazani na emigrację powojenna historiografia komunistyczna pieczołowicie usuwała z listy sygnatariuszy Deklaracji Niepodległości, przypisując zarazem przywódcom komunistycznej Albanii rolę kontynuatorów dzieła zapoczątkowanego we Vlorze.

\title{
THE NATION FATHERS (BABALLARET E KOMBIT). DESCRIPTION AND FORM OF ACTIVITIES OF ALBANIAN POLITICAL ELITES DURING FIRST BALKAN WAR
}

\begin{abstract}
Summary
The process of creation of Albanian modern State had a crucial point in November 1912, during First Balkan War. The group of Albanian national activists from southern part of Albania and from some diaspora communities gathered in Vlora to proclaim independence of Albanian State. In the specific circumstances created by war, only a part of invited delegates could attend in Vlora meeting. The analysis of their age, profession and religious affilation showed significant differences in comparison with contemporary Albanian society. Majority of Albanian acitivists and insurgents (among them very influential Kosovo Albanians) was marginalised in the the first phase of creation of Albanian State. The problem of representativeness of delegates in Vlora was one of the main obstacle in the cooperation of Albanians in the times of Principality of Albania (1912-1914).
\end{abstract}

